\title{
Urgences
}

\section{Tu viendras...}

\section{Maurice Richard}

Numéro 13, mars 1986

\section{Éclats d'atelier}

URI : https://id.erudit.org/iderudit/025219ar

DOI : https://doi.org/10.7202/025219ar

Aller au sommaire du numéro

\section{Éditeur(s)}

Urgences

\section{ISSN}

0226-9554 (imprimé)

1927-3924 (numérique)

Découvrir la revue

\section{Citer ce document}

Richard, M. (1986). Tu viendras... Urgences, (13), 45-46. https://doi.org/10.7202/025219ar

Ce document est protégé par la loi sur le droit d'auteur. L'utilisation des services d'Érudit (y compris la reproduction) est assujettie à sa politique d'utilisation que vous pouvez consulter en ligne.

https://apropos.erudit.org/fr/usagers/politique-dutilisation/ 


\section{Maurice Richard}

Tu viendras, la clé est toujours sur la porte. Ces paroles, elle les lui a dites si souvent. Pourtant il se promène en suçant sa grosse bière, arrête au Passe-Partout. Je lui plais, j'en suis certain, pensait-il.

- Comme d'habitude, Aubert/ - Une grosse ou une p'tite/ - Tu m'énerves, j'ai dit comme d'habitude/ - C'était une farce, Denis/ Change-la de temps en temps/ - Tu m'as dit comme d'habitude/ Merde, pourquoi je viens ici moi/ - La clé est toujours sur la porte/ - T'as le đon à soir, blasphème/ - Tu manques de sexe toé, c'est certain/ - J'ai tout le sexe qu'il me faut/ - J'aimerais voir ça/ - Eille, pousse tes bouteilles, on t'en demande pas plus/ - Toé non, mais d'autres oui/ Bon, salut, tu me tannes avec tes paraboles/

II se remet à marcher, suit deux individus et tend l'oreille.

- Connais-tu la différence/ - Fuck, je n'aime pas les histoires de différence/ - Sais-tu comment une maman lapine/ - Encore moins les légendes/ - Une fois un Anglais et un Québécois/ - Etouffe, je badtrippe assez comme ça/ - T'es dolle quand t'es saoul/ - J'arrête ici, les danseuses ont de l'allure cette semaine/

Ce dialogue le distrait, il accélère et rejoint deux autres fêtards sortant du chic Club Sandwich. - As-tu vu plus con que ce politicien/ - II s'agit qu'il porte un habit et te voilà piqué au vif/ - T'es pas capable de lire entre les lignes, tu gobes tout comme une tirelire d'enfant - $\grave{A}$ force de croire que l'essentiel est entre les lignes, tu oublies aussi qu'il y a des lignes et quelque chose d'écrit dessus/ - Voyons, les mots ne servent à rien, tu peux te boucher les oreilles et sentir la vérité/ - T'es pire que nos. curés qui, eux, nous parlaient en latin pour rendre leurs odeurs aux vérités/ - On accuse aussi les féministes de prendre la place des curés avec leur censure/ - Cette vérité, tu l'as sentie entre quelles lignes/ - J'ai 
jamais connu quelqu'un d'aussi biaisé que toi/ - C'était pour rire beau champignon/

À deux pas de chez elle, tranquillement, il avance, retrouve cette porte protégée par un barrage de bottes, de souliers et de bottines. La clé est là. Elle est laide après tout, pense-t-il, avec son nez trop long, sa bouche étroite, ses yeux trop rapprochés, son menton avancé, en plus elle marche avec la tête un peu trop haute et parle à trop de monde. donner.

Denis retourne au bar avec un vague besoin de se faire par- 